\title{
Using Expert Panel Data to Guide Youth Agricultural Safety and Health Training Resources in the US
}

\author{
Andrew J. Mann * and S. Dee Jepsen \\ Department of Food, Agricultural, and Biological Engineering, The Ohio State University, 590 Woody Hayes \\ Drive, Columbus, OH 43210, USA; jepsen.4@osu.edu \\ * Correspondence: mann.309@osu.edu; Tel.: +1-614-292-1952 \\ Academic Editor: Dennis Murphy \\ Received: 1 July 2016; Accepted: 13 December 2016; Published: 1 January 2017
}

\begin{abstract}
The US Department of Labor (US DOL) oversees the Agricultural Hazardous Occupations Orders (AgHOs), which identifies specific tasks that youth are prohibited from performing for hire on American farms and ranches. An educational exemption from this public policy is currently in place that allows youth, 14-15 years old, to complete a certification program prior to engaging in agricultural work involving tractors and machinery. However, limited guidance is provided in the legislation regarding the format or content of the tractor and machinery certification exemption. Four AgHOs (tractor and machinery) studies were identified and included in this meta-analysis publication. The research goals of this analysis were to determine basic trends of learning outcomes, and identify educational content to be delivered as a result of these studies. Within each of the four studies, expert panels were used to identify educational learning outcomes. The analysis revealed that $48.0 \%(n=184)$ of all learning outcome items fell within the Tractor-based (Tractor) learning outcome category, 29.8\% $(n=114)$ within General Safety and Health (General), and 22.2\% $(n=85)$ of items in the Machinery-based (Machinery) category. Ultimately, sound educational methods and understanding of fundamental student competence are essential components for any training program, including youth who complete AgHOs tractor and machinery certification programs.
\end{abstract}

Keywords: agricultural safety; expert panel; Agricultural Hazardous Occupations Orders (AgHOs); youth; youth certification; tractor safety; safety education

\section{Introduction}

Since 1970, the US Department of Labor (US DOL) has provisions in the Fair Labor Standards Act (FLSA) to oversee child labor where it applies to farms and ranches [1]. This public policy is known as the Agricultural Hazardous Occupations Orders (AgHOs). Although agricultural practices and technology have changed, the AgHOs have remained largely unchanged since their inception.

The AgHOs identify eleven tasks deemed too hazardous for youth employment. These eleven tasks, listed in Figure 1 can be categorized as work completed with the following systems: 1 . Tractor; 2. General Machinery; 3. Specialized Machinery; 4. Livestock; 5 . Woodlot; 6 . Ladder and Scaffold; 7. Transport; 8. Toxic Atmosphere; 9. Chemicals; 10. Blasting; and 11. Fertilizers. 


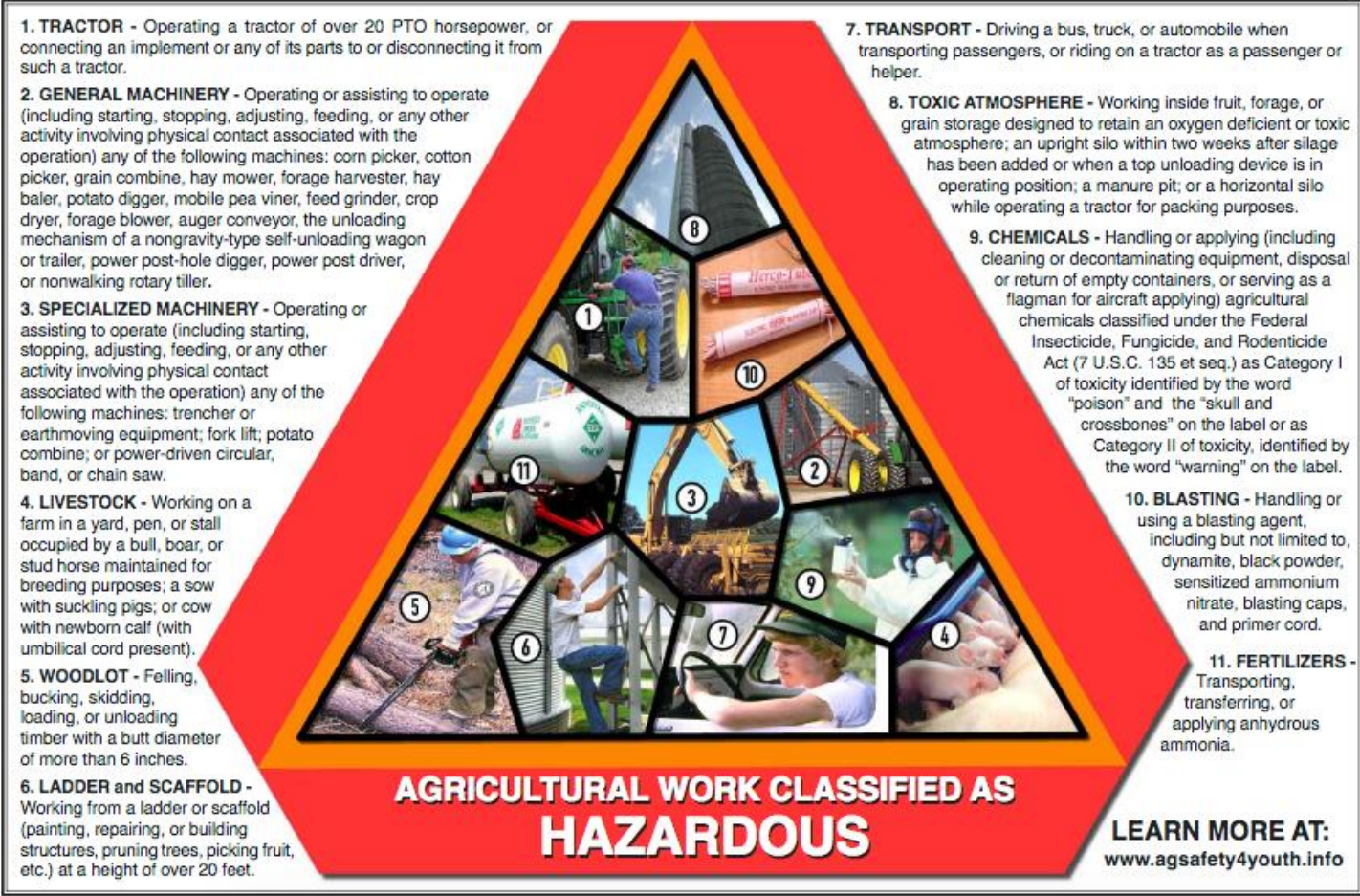

Figure 1. Employment of youth in agriculture: The law, training programs, and tasks classified as hazardous. Source: agsafety4youth.info [2].

The US DOL has allowed three exemptions to their federal ruling for allowing youth to work in areas of agriculture identified as hazardous. The three exemptions include:

(a) Youth working on an operation owned by their parent or legal guardian are allowed unrestricted employment opportunities (AgHOs 1-11)

(b) Youth enrolled in a high school agricultural education program (i.e., formerly vocational agriculture) are permitted to be employed, providing that certain documentation requirements are met (AgHOs 1-6), or

(c) Youth who complete an education training program, commonly known as a tractor and machinery certification course, offered through the federal Extension service or by agricultural education are eligible for employment (AgHOs 1-2).

The scope of this paper will focus around exemption number three in which youth, ages 14-15 years old, are required to complete a training program and become certified prior to operating tractors and/or machinery for hire. Traditionally, these tractor and machinery training programs were state or locally based and often guided by either the 4-H Petroleum Power Program booklet [3] or the Safe Operation of Agricultural Equipment [4], commonly referred to as the HOBAR manual, which identifies the publisher of this book. The 4-H booklet has since been discontinued, while the HOBAR manual has been republished with minor edits related to its content over the past two decades [5].

There is very little documentation, and no formal reporting system, of tractor and machinery training programs being conducted across the US. Anecdotally, agricultural safety and health professionals are aware of these programs offered by both state and local auspices; however, the number of instructors and the specific content being taught in these programs is usually unknown outside of each professional's home state. The lack of compliance standards requiring instructors to register their programs has resulted in difficulty tracking the number and types of training being offered [6]. 
A review of the literature revealed four studies aimed specifically at identifying learning outcomes for tractor and machinery certification programs. These four studies are described below and provide the basis for this research paper. The authors acknowledge other certification programs may be available on a localized level, however, such programs were not included in this publication because documentation of their research methods and/or curriculum development process was not found in the literature.

\subsection{Wisconsin Safe Operation of Tractor and Machinery (WI-SOTM)}

Subsequent to the 4-H book and HOBAR manual, the earliest documented study was undertaken following state legislation in the early 1990s. Shortly after Wisconsin Act 455 [7], the Wisconsin Safe Operation of Tractor and Machinery certification program (WI-SOTM) was developed by the National Institute for Occupational Safety and Health (NIOSH) supported Wisconsin Center for Agricultural Safety and Health [8]. An expert panel consisting of both agricultural safety and health experts and Extension educators was used to reaffirm state and federal requirements for child labor in agriculture to develop the WI-SOTM curriculum. This expert panel identified 42 learning objectives from which the WI-SOTM curriculum was developed.

\subsection{National Safe Tractor and Machinery Operation Program (NSTMOP)}

In 2001, the United States Department of Agriculture, National Institute for Food and Agriculture (USDA-NIFA), funded a project to develop an educational safety program titled the National Safe Tractor and Machinery Operation Program (NSTMOP) [9]. The project was led by Pennsylvania State University, with additional curriculum developers at Ohio State University and National Safety Council. A segment of this study was to convene a panel of agricultural safety and health experts that identified minimum core content areas or learning outcomes for a new curriculum. This study identified over 275 concepts that eventually lead to the development of 77 educational safety task sheets with 48 of those being designated "core" or critical to youth's understanding prior to employment in agriculture occupations [10].

\subsection{Gearing Up for Safety (Gearing Up)}

A research effort sponsored by the Centers for Disease Control and Prevention-National Institute for Occupational Safety and Health (CDC-NIOSH) in the late 1990s identified core competencies to explore the effectiveness of a computer-based curriculum [11]. The primary aim of this effort was to focus on the most critical cognitive and skill related competencies that youth need to acquire in order to be safe workers and operators of agricultural tractors. The literature depicts collecting validity evidence for competencies through use of an expert panel and a final review from end user groups, in this case high school agricultural educators and high school aged youth. The result was an outline for 12 educational units containing 170 competencies. USDA-NIFA successively funded additional projects that translated the competencies into the Gearing Up for Safety (Gearing Up) curriculum [12]. During a subsequent project, 157 cognitive based competencies were utilized for development of exam items (i.e., test questions) to be used in the tractor and machinery certification process [13].

\subsection{National Assessment of Tractor and Machinery Certification Programs (NA-TMCP)}

Jepsen conducted an independent study in 2006 to determine program goals and students competencies for the tractor and machinery certification programs [14]. The National Assessment of Tractor and Machinery Certification Programs (NA-TMCP) study used a mixed-mode approach by surveying both community-based instructors and agricultural safety and health professionals. Using a modified Delphi method, a panel of experts identified eight overarching program objectives and 117 student competencies [14] (p. 190). This data was verified using a frame of 467 program instructors in 33 US states [14] (pp. 161-162). 


\subsection{Other Supporting Effort—North American Guidelines for Children's Agricultural Tasks}

Research conducted by the National Children's Center for Rural and Agricultural Health and Safety identified age appropriate tasks for youth, ages 7-16 years old, working in agriculture [15]. The primary focus of this consensus document entitled North American Guidelines for Children's Agricultural Tasks (NAGCAT) was not to develop teaching materials, but rather to assist parents with assigning specific age appropriate tasks to children working on agricultural operations, and have since been updated to reflect more recent trends in agricultural injury data [16]. Due to the fact that NAGCAT did not identify learning outcomes nor develop training materials, this effort was not included in the analysis of this publication.

\section{Methods}

Expert panels have been used in the areas of agricultural education, extension, and agricultural safety and health to identify learning outcomes, develop curriculum, and provide a form of consensus for making training recommendations [6,14,17-25]. Based on a review of literature, four studies that identified learning outcomes specifically for tractor and machinery certification were utilized for analysis in this paper. Three of these studies translated their research into development of up-to-date educational curricula while the fourth focused only on identification of learning outcomes. For this reason, any of the collective four studies will now be referred to as programs or studies instead of curriculum.

The four programs identified from the literature include: Wisconsin Safe Operation of Tractor and Machinery certification program (WI-SOTM), National Safe Tractor and Machinery Operation Program (NSTMOP), Gearing Up for Safety (Gearing Up), and a National Assessment of Tractor and Machinery Certification Programs (NA-TMCP).

\subsection{Overview}

Independent expert panels were utilized in the development of the 383 learning outcomes collectively identified from the four programs. The learning outcomes from these four programs served as the basis for analysis of this paper. The learning outcomes are summarized by program and type of outcome in Table 1.

Table 1. Summarization of Learning Outcomes by Program and Type.

\begin{tabular}{cccccc}
\hline & WI-SOTM & NSTMOP & NA-TMCP & Gearing Up & TOTAL \\
\cline { 2 - 6 } & $\mathbf{4 2}$ & $\mathbf{4 8}$ & $\mathbf{1 1 7}$ & $\mathbf{1 7 6}$ & $\mathbf{3 8 3}$ \\
\hline Outcome Type & Objectives & $\begin{array}{c}\text { Minimum Core } \\
\text { Content Areas }\end{array}$ & Competencies & Competencies & \\
\hline
\end{tabular}

\subsection{Categorization of Learning Outcomes}

Organization of learning outcomes into subcategories was necessary as two of the studies identified competencies, one identified core content areas, and another program developed objectives. A database was established, combining the learning outcomes from each of the four programs into a single Microsoft Excel spreadsheet.

The initial stage of categorization was to separate the learning outcomes into three broad primary categories: General Safety and Health-related, Tractor-related, and Machinery-related learning outcome items. Each item was classified based on terminology and information contained in the lesson plan or chapter of each respective study. The learning outcomes were then subcategorized into 20 more specific secondary classifications as shown in Table 2. 
Table 2. Secondary Sub-Classification System.

\begin{tabular}{ccc}
\hline General Safety and Health & Tractor & Machine \\
\hline G1-Regulations and Laws & T1-Regulations and Laws & M1-Regulations and Laws \\
\hline $\begin{array}{c}\text { G2-Identification (ID) of } \\
\text { Hazard Agents }\end{array}$ & T2-ID of Hazard Agents & M2-ID of Hazard Agents \\
\hline $\begin{array}{c}\text { G3-Injury Prevention } \\
\text { Devices/Methods }\end{array}$ & $\begin{array}{c}\text { T3-Injury Prevention } \\
\text { Devices/Methods }\end{array}$ & $\begin{array}{c}\text { M3-Injury Prevention } \\
\text { Devices/Methods }\end{array}$ \\
\hline G4-All-Terrain Vehicles (ATVs) & T4-Rollover Protective & System (ROPS) \\
\hline & $\begin{array}{c}\text { T5-Preventative Maintenance } \\
\text { and Pre-Operational Checks }\end{array}$ & $\begin{array}{c}\text { M5-Preventative Maintenance } \\
\text { and Pre-Operational Checks }\end{array}$ \\
\hline & $\begin{array}{c}\text { T6-Tractor Controls, } \\
\text { Functions, and Symbols }\end{array}$ & $\begin{array}{c}\text { M6-Stationary vs. } \\
\text { Mobile Equipment }\end{array}$ \\
\hline & T7-Connecting Implements & M7-Connecting Implements \\
\hline
\end{tabular}

The three main classifications were labeled G (General), T (Tractor), and M (Machinery), based on language from the federal legislation. The individual programs were placed in the spreadsheet starting with the lowest number of learning outcomes. The secondary classification system was structured beginning with the WI-SOTM program since this program had the fewest number of broadly defined learning outcomes.

After scanning all four educational programs for common trends in learning outcome content, the secondary abbreviation G1-Regulations and Laws was created based on WI-SOTM objective number 1-Youth will increase their knowledge of regulations regarding child labor laws and youthful operators of tractors and farm machinery and NSTMOP task sheet number 1.2-Safety and Health Regulations. Each secondary subcategory included an option for outcomes to be classified as "Too Broad or Too Specific to be Subcategorized". This initial organization method worked well as the programs with fewer learning outcomes were predominantly general in scope. The outcomes were then further sub-classified into tertiary categories with a goal to maintain mutually exclusive categories, allowing each learning outcome to fit only into one category, which provided specific trends of the learning outcomes. Tertiary classifications for G1-Regulations and Laws mentioned above include G1.1-Federal Regulations, and G1.2-State Regulations. An abbreviated example of this classification process is depicted in Figure 2.

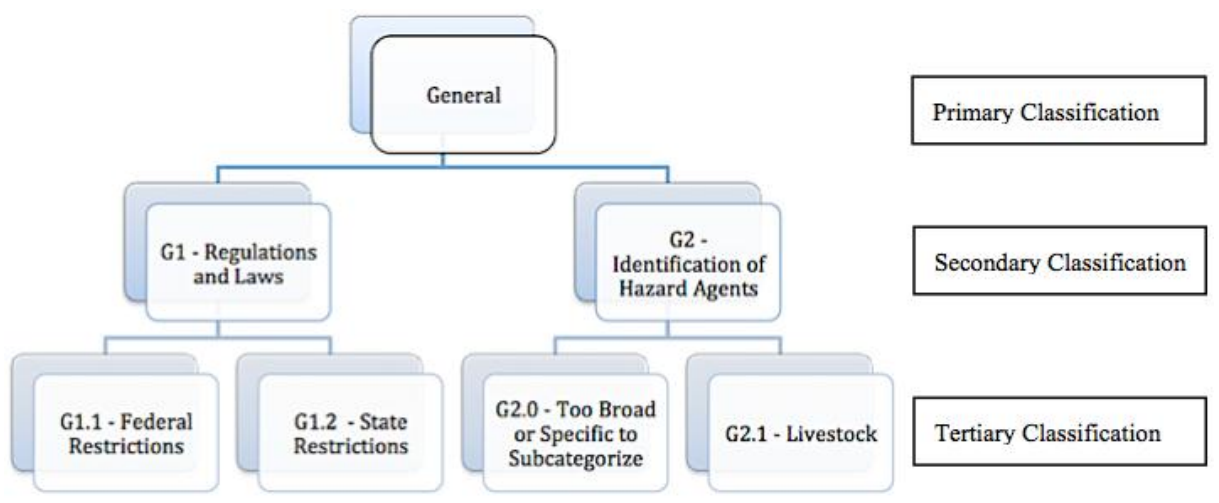

Figure 2. Learning Outcome Hierarchical Classification Example.

Using the abbreviated classification system shown in Figure 2, outcomes were then subcategorized again into 116 specific, tertiary classifications as shown in Table 3. 
Table 3. Select Tertiary Sub-Classification Categories.

\begin{tabular}{ccc}
\hline General Safety and Health & Tractor & Machine \\
\hline $\begin{array}{c}\text { G1.0-Too Broad or Specific } \\
\text { to be Subcategorized }\end{array}$ & $\begin{array}{c}\text { T1.0-Too Broad or Specific } \\
\text { to be Subcategorized }\end{array}$ & $\begin{array}{c}\text { M1.0-Too Broad or Specific } \\
\text { to be Subcategorized }\end{array}$ \\
\hline G1.1-Federal Regulations & T1.1-Federal Regulations & M1.1-Federal Regulations \\
\hline G1.2-State Regulations & T1.2-State Regulations & M1.2-State Regulations \\
\hline G2.2-Chemicals/Pesticides & T2.2-Obstacles & M2.2-Obstacles \\
\hline $\begin{array}{c}\text { G3.1-Personal Protective } \\
\text { Equipment (PPE) }\end{array}$ & $\begin{array}{c}\text { T3.1-Personal Protective } \\
\text { Equipment (PPE) }\end{array}$ & $\begin{array}{c}\text { M3.1-Personal Protective } \\
\text { Equipment (PPE) }\end{array}$ \\
\hline $\begin{array}{c}\text { G3.7-Using Senses to } \\
\text { Detect Hazards }\end{array}$ & $\begin{array}{c}\text { T3.7-Roll-Over Protective } \\
\text { System (ROPS) }\end{array}$ & $\begin{array}{c}\text { M3.7-Falling Object } \\
\text { Protective Structure (FOPS) }\end{array}$ \\
\hline G4.1-[ATV] Hazards & T8.3-Starting and Stopping & M8.3-Powering \\
Down Implements
\end{tabular}

\subsection{Statistical Analysis}

Descriptive analyses were conducted to generate frequency and percentage, in addition to basic correlation analyses using cross-tabulations with chi-square tests. The cross-tabulation with chi-square test was chosen over other methods as the data were categorical rather than $2 \times 2$, and were descriptive rather than experimental. Minitab 16 was used for these analyses [26]. The overarching goals were to compare the four studies and determine basic trends of learning outcomes across the three main classifications; G (General), T (Tractor), and M (Machinery).

\section{Results}

The content contained in the four tractor and machinery programs allowed natural breaks within three primary categories. Overall, 29.8\% $(n=114)$ of all learning outcomes fell within the General Safety and Health (General) primary category, $48.0 \%(n=184)$ within Tractor-Based (Tractor), and $22.2 \%(n=85)$ of outcomes in the Machinery-Based (Machinery) category. Figure 3 provides a pictorial representation of the distribution of data among the four programs.

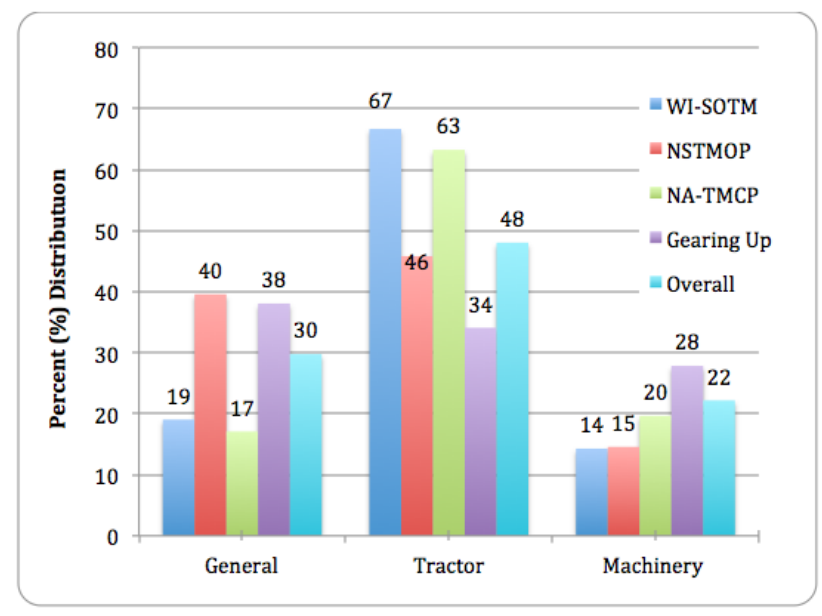

Figure 3. Distribution of Primary Categories across the Four Programs.

Across the four programs, the National Safety Tractor and Machinery Operation Program (NSTMOP) and Gearing up for Safety (Gearing Up) studies placed the greatest emphasis on General items (39.6\% and 38.1\% respectively). The Wisconsin Safe Operation of Tractors and Machinery (WI-SOTM) program and the National Assessment of Tractor and Machinery Certification Programs (NA-TMCP) place the greatest emphasis on Tractor related learning outcomes $(66.7 \%$ and $63.3 \%$ 
respectively). Table 4 provides a detailed summary of the count and percentage of learning outcomes within each primary category.

Table 4. Learning Outcome Count and Percentage within the Primary Categories. $(n=383)$. $(p$-value $<0.001$, Alpha $=0.05$, Chi-Square $=34.710)$.

\begin{tabular}{cccccc}
\hline \multirow{2}{*}{ Primary Categories } & \multicolumn{4}{c}{ Program/Study } & \multirow{2}{*}{ Overall } \\
\cline { 2 - 5 } & WI-SOTM & NSTMOP & NA-TMCP & Gearing Up & \\
\hline General Safety and Health (\%) & $8(19.1)$ & $19(39.6)$ & $20(17.1)$ & $67(38.1)$ & $114(29.8)$ \\
Tractor (\%) & $28(66.7)$ & $22(45.8)$ & $74(63.3)$ & $60(34.1)$ & $184(48.0)$ \\
Machinery (\%) & $6(14.3)$ & $7(14.6)$ & $23(19.7)$ & $49(27.8)$ & $85(22.2)$ \\
Total (\%) & $42(100)$ & $48(100)$ & $117(100)$ & $176(100)$ & $383(100)$ \\
\hline
\end{tabular}

The Gearing Up Tractor category provided the highest contribution to the Pearson chi-square value of 34.710. Factors that were significant include Gearing Up Tractor $X^{2}(6, n=60)=7.130, p<0.01$, followed by NA-TMCP General X ${ }^{2}(6, n=20)=6.311, p<0.01$, and NA-TMCP Tractor $X^{2}(6, n=22)=5.631, p<0.01$. Each cell's contribution to the chi-square value is summarized in Table 5.

Table 5. Contribution of Each Cell to Chi-Square Independence Test $\left(X^{2}\right)$.

\begin{tabular}{ccccc}
\hline \multirow{2}{*}{ Category } & \multicolumn{4}{c}{ Program/Study } \\
\cline { 2 - 5 } & WI-SOTM & NSTMOP & NA-TMCP & Gearing Up \\
\hline General & 1.621 & 1.555 & 6.311 & 4.077 \\
Tractor & 3.033 & 0.049 & 5.631 & 7.130 \\
Machinery & 1.183 & 1.252 & 0.339 & 2.530 \\
\hline
\end{tabular}

The analysis of secondary sub-classified outcomes revealed significance at the $p<0.01$ level, $\mathrm{X}^{2}(42, n=112)=118.19$. The initial evaluation was for all learning outcomes among the four programs, in order to identify trends among the outcomes. The ten most prevalent outcomes, ordered by study and highest percent were: WI-SOTM T8, NSTMOP G2, NA-TMCP T8, and T5, Gearing Up G3, G2, M2, M3, T3, and T8. The frequency, percent of total, and contribution to chi-square value is reported for these ten learning outcomes, along with a description of each outcome in Table 6.

Table 6. Secondary Learning Outcomes with Highest Frequency, by Program.

\begin{tabular}{ccccl}
\hline Frequency & Percent of Total & Contribution to $\mathbf{X}^{\mathbf{2}}$ & Category Abbrev. & Program-Description of Category \\
\hline 32 & 8.355 & 7.927 & T8 & NA-TMCP-Tractor Operation \\
\hline 28 & 7.311 & 1.601 & G3 & Gearing Up-Injury Prevention Devices/Methods \\
\hline 24 & 6.266 & 0.2672 & G2 & Gearing Up-Identification of Hazard Agents \\
\hline 23 & 6.005 & 9.5114 & T5 & $\begin{array}{l}\text { NA-TMCP-Preventative Maintenance and } \\
\text { Pre-Op Checks }\end{array}$ \\
\hline 20 & 5.222 & 2.8011 & M2 & Gearing Up-Identification of Machinery Hazards \\
\hline 16 & 4.178 & 6.0516 & M3 & $\begin{array}{l}\text { Gearing Up-Machinery Injury Prevention } \\
\text { Devices/Methods }\end{array}$ \\
\hline 15 & 3.926 & 2.366 & T3 & $\begin{array}{l}\text { Gearing Up-Tractor Injury Prevention } \\
\text { Devices/Methods }\end{array}$ \\
\hline 13 & 3.394 & 9.156 & T8 & Gearing Up-Tractor Operation \\
\hline 12 & 3.133 & 3.536 & T8 & WI-SOTM-Tractor Operation \\
\hline 11 & 2.872 & 4.432 & G2 & NSTMOP-Identification of Hazard Agents \\
\hline
\end{tabular}

The analysis of secondary learning outcomes revealed many cells with less than five values: this is an indicator that the chi-square values may not provide a valid comparison and should be interpreted with 
caution. Based on this finding, data for all programs were combined and analyzed by secondary category. When looking at the secondary category level, the five most prevalent outcomes, ordered highest percent of total outcomes were: T8-Tractor Operation, G3-Injury Prevention Devices/Methods, G2-ID of Hazards Agents, T5-Preventative Maintenance and Pre-Operational Checks, and M2-Identification of Machinery Hazards. The five most common categories comprised 229 learning outcomes, or $59.8 \%$ of all outcomes. The frequency, percent of total, and contribution to chi-square value is reported for these five categories, along with a description of each category in Table 7.

Table 7. Secondary Learning Outcomes with Highest Frequency, by Category.

\begin{tabular}{ccccc}
\hline Frequency & Percent of Total & Contribution to $\mathbf{X}^{\mathbf{2}}$ & Category Abbrev. & Description of Category \\
\hline 64 & 16.710 & 20.749 & $\mathrm{~T} 8$ & Tractor Operation \\
48 & 12.533 & 3.801 & $\mathrm{G} 3$ & Injury Prevention Devices/Methods \\
47 & 12.272 & 7.952 & $\mathrm{G} 2$ & Identification of Hazard Agents \\
40 & 10.444 & 15.230 & $\mathrm{~T} 5$ & Preventative Maintenance and Pre-Op \\
30 & 7.833 & 5.945 & $\mathrm{M} 2$ & Identification of Machinery Hazards \\
154 & 40.208 & 64.509 & - & All Other Learning Outcomes \\
$\mathbf{3 8 3}$ & $\mathbf{1 0 0 . 0 0 0}$ & $\mathbf{1 1 8 . 1 8 7}$ & - & TOTAL \\
\hline
\end{tabular}

The analysis of tertiary sub-classified learning outcomes revealed significance $\mathrm{X}^{2}(42, n=448)$ $=118.19, p<0.01$. Similar to previous sub-classification analysis, many cells had values less than five. This result was expected as the classification into mutually exclusive categories spread the 383 outcomes across more cells and reduced the average number of items per cell.

From a comparison of tertiary sub-categories, seven of the 448 comparisons resulted in a frequency greater than 10. T8.6-Operating on Public Roadways was the most common tertiary item. The frequency and description of the ten most referenced tertiary learning outcomes by program are provided in Table 8 .

Table 8. Tertiary Learning Outcomes with Highest Frequency, by Program.

\begin{tabular}{|c|c|c|c|c|c|c|}
\hline $\begin{array}{l}\text { Cumulative } \\
\text { Frequency }\end{array}$ & WI-SOTM & NSTMOP & NA-TMCP & Gearing Up & $\begin{array}{l}\text { Category } \\
\text { Abbrev. }\end{array}$ & Description \\
\hline 20 & 5 & 2 & 9 & 4 & T8.6 & Operating on Public Roadways \\
\hline 14 & 2 & 7 & 1 & 4 & T6.1 & Controls, Gauges, and Instrument Panel \\
\hline 13 & 0 & 1 & 1 & 11 & G3.4 & First Aid \\
\hline 13 & 0 & 1 & 11 & 1 & T5.2 & Inspections and General Maintenance \\
\hline 10 & 0 & 4 & 0 & 6 & G2.4 & Confined Spaces \\
\hline 10 & 1 & 2 & 4 & 3 & G3.1 & Personal Protective Equipment (PPE) \\
\hline 10 & 1 & 1 & 4 & 4 & T8.3 & Starting and Stopping \\
\hline 293 & 33 & 30 & 87 & 143 & - & All Other Learning Outcomes \\
\hline 383 & 42 & 48 & 117 & 176 & - & TOTAL \\
\hline
\end{tabular}

\section{Discussion}

The Agricultural Hazardous Occupations Orders (AgHOs) certification exemption contained in Title 29, Part 570, Subpart E-1 of the Code of Federal Regulations identifies the hours of instruction required by youth who are enrolled a tractor and machinery certification program. The regulations require youth to complete a 24-h training program that emphasizes tractor-related content for $10 \mathrm{~h}$ (representing $41.7 \%$ of the total training contact hours), machinery for $10 \mathrm{~h}(41.7 \%)$ and four hours of general farm safety and health (16.6\%). The federal regulations specifically identify hours of instruction as the primary rubric for training, with little guidance for establishing educational content and student competence beyond a generalized testing procedure to include a written exam and driving test.

Curriculum development educators of four different programs relied on expert panels and personal field experience to develop certification programs to be used on the national level. These four studies identified learning outcomes based on the three primary categories outlined in tractor and machinery certification, but did not predetermine or limit the percentage of learning outcome items for each category. 
From this descriptive research study, the strongest emphasis across all four programs was the Tractor (48.0\%). The tractor is a common item found on a majority of US farms and continues to be the leading fatality agent for farms and agribusiness $[27,28]$. Weighted by proportion, this overall average of curriculum content $(48.0 \%$ ) aligns closely with the federal exemption recommendation of $41.7 \%$ for tractor training contact time.

The largest discrepancy between the four studies and the federal recommendations is in regards to the General Safety and Health category. The four programs placed more emphasis on general safety and health knowledge with $29.8 \%$ distribution of all items compared to a recommended $16.6 \%$ of total contact time (i.e., hours of instruction) outlined in the regulations. The tertiary general safety and health items identified by highest combined frequency across all four studies included; First Aid and actions taken in the event of emergencies (item G3.4, $n=13$ ), Confined Spaces (i.e., grain bins, manure storage, and fruit storage) (item G2.4, $n=10$ ), and Personal Protective Equipment-PPE (item G3.1, $n=10$ ). The learning outcomes in these three specific tertiary categories included work practices that could be applied to other agricultural tasks, not just tractor and machinery operation.

Based on the federal recommendations, machinery related content requires the same level of instruction as the tractor $(41.6 \%)$. However, this area received the lowest proportion across the four studies $(22.2 \%)$. Several observed key points from the specific training material (i.e., lighting and marking concerns and use of a universal color coding system for controls and components) was included in the tractor section of most programs. While the concepts such as displaying a Slow Moving Vehicle (SMV) emblem and proper coloring of controls can easily be applied from tractors to machinery, the program developers decided not to duplicate material in most instances.

In September 2011, the US DOL posted a Notice of Proposed Rulemaking (NPRM) in the Federal Register [29]. The proposal sought to update the plus 40-year old legislation language in the $\mathrm{AgHOs}$, as well as provide stricter regulation, or enhanced protection for youth working in agriculture. The NPRM suggested removing the "24-h" training exemption and placing responsibility solely on high school agricultural education programs when training was provided. The US DOL proposed that students complete $90 \mathrm{~h}$ of systematic instruction at or above the eighth-grade level prior to being eligible to perform certain agricultural tasks. At the conclusion of the public comment period, the NPRM was withdrawn, leaving the 1970 AgHOs in place.

At the same time as the US DOL NPRM discussion, a national study of tractor and machinery certification programs found instructors to be more interested in student competence than total hours of instruction [30]. This study of 330 course instructors (both Extension and high school agricultural education teachers) reported spending a total time-weighted average of $30.05 \mathrm{~h}$ of instruction towards Tractor, Machinery, and General Safety and Health topics. This amount of time was higher than the current US DOL program requirements and merely one third of the 90 contact hours proposed in the NPRM. Regardless of the hours spent on student instruction, teachers felt strongly that priority be given to standardized teaching materials as well as up-dated teaching materials, and not focus on hours of student instruction. These instructors also identified key programmatic factors that play a role in the successful delivery of the tractor and machinery training, such as instructors' awareness of the federal certification program requirements, their amount of administrative support to offer training programs, and their available time and flexibility to address subject matter outside of their state performance standards.

In 2013, the US Department of Agriculture, National Institute of Food and Agriculture (NIFA) funded the Safety in Agriculture for Youth (SAY) initiative [31]. This national project sought to improve and increase safety education resources for youth. Such resources were categorized and placed into an electronic, accessible National Clearinghouse, for access by formal and non-formal program instructors. A significant contribution of this effort was to develop a process that aligned curricula and resources to current nationally recognized learning outcomes that educators could also match to their state educational standards or guidelines. Specifically, content on the National Clearinghouse was aligned to 
the National Agriculture, Food, and Natural Resources (AFNR) Career Cluster Standards, developed by The National Council for Agricultural Education (NCAE) [32].

The overtones of these external factors surrounding the US DOL's NPRM support the research performed in this descriptive analysis. Understanding the legislation, the youth training exemptions, instructors' preference for competency based curricula, and the recent initiative to increase training materials that meet the NCAE's AFNR Career Cluster Standards, are key implications of a viable training program for US youth working in agriculture.

This descriptive study did not evaluate student competence, or instruments for assessment of student competence (i.e., tests/exams). A plausible next step would be evaluation of exam items (i.e., test questions) for alignment to the learning outcomes described in this document.

\section{Conclusions}

This descriptive analysis of four different studies provides readers with a synopsis of the learning outcome development research conducted in a specialized area of youth training. Likewise, these data assist curriculum designers and local instructors of tractor and machinery certification programs to meet current training requirements of the regulations, and provide additional guidance on specific educational topics that should be addressed by their respective program.

The expert panels used in these four national studies were consistent in identifying learning outcomes with a focus on agricultural tractors. Specific learning outcomes relating to Tractor Operation (T8), and Preventative Maintenance and Pre-Operation Checks were the most frequently identified learning outcomes. Tractor operation, specifically operation on public roadways, was an item of importance to the collective body of experts in these studies. The Gearing Up and NA-TMCP panels felt strongly about the importance of All-Terrain Vehicles (ATV) (G4) education in these training programs. This ranking placed heavy emphasis on the importance for youth to be trained on the safe operation of these vehicles.

The use of expert panels in consensus building is a well-established practice in the area of agricultural safety and health [6,14,17-25]. Future certification programs and enhancements of current programs can be analyzed utilizing expert panel methods. The findings from this research were designed to assist individuals with involvement in public policy, curriculum design, youth development, and agricultural training programs. Ultimately, sound educational methods and understanding of fundamental student competence are essential components for satisfying exemptions to the US Department of Labor's Agricultural Hazardous Occupations Orders (AgHOs), in addition to similar certification programs for youth.

Acknowledgments: Support for this study was provided by the Ohio Agricultural Research and Development Center (OARDC) at The Ohio State University.

Author Contributions: This study was completed by Andrew Mann as partial requirements for a Doctoral degree, under the direction of advisor S. Dee Jepsen. Mann and Jepsen conceived and designed the framework for this descriptive study. Mann analyzed the data with guidance from Jepsen. Mann and Jepsen contributed equally to the authorship of this paper.

Conflicts of Interest: The authors declare no conflict of interest. The sponsors had no role in the design of the study; in the collection, analyses, or interpretation of data; in the writing of the manuscript, and in the decision to publish the results.

\section{References}

1. United States Department of Labor. Child Labor Requirements in Agricultural Occupations under the Fair Labor Standards Act. Available online: http://www.dol.gov/esa/whd/regs/compliance/childlabor102.pdf (accessed on 19 May 2016).

2. Employment of Youth in Agriculture: The Law, Training Programs, and Tasks Classified as Hazardous [Informational Poster]. Available online: http:/ / agsafty4youth.info (accessed on 14 January 2016). 
3. National 4-H Council and Standard Oil Company. Leader's Guide 4-H Petroleum Power Program; National 4-H Petroleum Power Program Development Committee, USDA Cooperative Extension Service: Washington, DC, USA, 1963.

4. Silletto, T.A.; Hull, D.O. Safe Operation of Agricultural Equipment; HOBAR Publications: St. Paul, MN, USA, 1976.

5. Silletto, T.A.; Hull, D.O. Safe Operation of Agricultural Equipment; HOBAR Publications: St. Paul, MN, USA, 1996.

6. Snyder, S.; French, B.; Field, W.; Tormoehlen, R.; Ess, D. Identification and Validation of Agricultural Hazardous Occupations Order Certification Program Instructor Criteria and Competencies. J. Agric. Educ. 2013, 54, 111-123. [CrossRef]

7. State of Wisconsin. 1993 Wisconsin Act 455, Sect. 10.346.925. Available online: http:/ /www.legis.state.wi. us/acts89-93/93Act455.pdf (accessed on 19 May 2016).

8. Schuler, R.T.; Skjolass, C.A.; Purschwitz, M.A.; Wilkinson, T.L. Wisconsin Youth Tractor and Machinery Certification Programs Evaluation. In Proceedings of the American Society of Agricultural Engineers Conference, St. Joseph, MI, USA, June 1994.

9. Hilton, J.W.; Murphy, D.J.; Bean, T. Establishing a National Safe Tractor and Machinery Operation Certification Program; FY2001 USDA-NIFA Awarded Grant: Washington, DC, USA, 2001.

10. Garvey, P.M.; Murphy, D.J.; Yoder, A.M.; Hilton, J.W. National Safe Tractor and Machinery Operation Program: Development and Content Evaluation. J. Agric. Saf. Health 2008, 14, 333-349. [CrossRef] [PubMed]

11. Ortega, R.; Tormoehlen, R.; Field, W.; Balschwied, M.; Machtmes, K. Determining critical subject matter content for a safety certification program for youth employed in agricultural production. J. Agric. Educ. 2003, 44, 67-79. [CrossRef]

12. Tormoehlen, R.; Field, W.; Fox, R.; Personett, C.; Vollmer, W.; Ortega, R. Gearing Up for Safety: Production Agricultural Safety Training for Youth; Purdue University: West Lafayette, IN, USA, 2003.

13. Mann, A.J.; Field, W.E.; Tormoehlen, R.; French, B.F. Development and Validation of Written Exam Items for the Agricultural Hazardous Occupations Orders (AgHOs) Certification Training Program. J. Agric. Saf. Health 2016, 22, 121-134. [PubMed]

14. Jepsen, S.D. Assessment of the U.S. Department of Labor's Tractor and Machinery Certification Program: A National Perspective. Ph.D. Thesis, The Ohio State University, Columbus, OH, USA, 2006.

15. Lee, B.; Marlenga, B. (Eds.) Professional Resource Manual: North American Guidelines for Children's Agricultural Tasks; Marshfield Clinic: Marshfield, WI, USA, 1999.

16. Hard, D.; Schwebel, D.C.; Ellis, T.; Marlenga, B. Updating the NAGCAT tractor guidelines to reflect the latest scientific evidence. J. Agromed. 2014, 19, 214. [CrossRef]

17. Archer, T.M. Focus groups for kids. J. Ext. 1993, 31, 3.

18. Bartels, S.; Niederman, B.; Waters, T.R. Job hazards for musculoskeletal disorders for youth working on farms. J. Agric. Saf. Health 2000, 6, 191-201. [CrossRef] [PubMed]

19. Duncan, S.F.; Marotz-Braden, R. Using focus groups to identify rural participant needs in balancing work and family education. J. Ext. 1999, 37, 4-19.

20. Holz-Clause, M.; Jost, M. Using focus groups to check youth perceptions of agriculture. J. Ext. 1995, 33, R10324.

21. Kingman, D.M.; Yoder, A.M.; Hodge, N.S.; Ortega, R.; Field, W.E. Utilizing expert panels in agricultural safety and health research. J. Agric. Saf. Health 2005, 11, 61-74. [CrossRef] [PubMed]

22. Mathew, S.N.; Field, W.E.; French, B.F. Content validation using an expert panel: Assessment process for assistive technology adopted by farmers with disabilities. J. Agric. Saf. Health 2011, 17, 227-241. [CrossRef] [PubMed]

23. Mulloy, K.B.; McDonald, M.; Gilmore, K. Cultivating an effective agricultural center advisory board. J. Agric. Saf. Health 1998, 4, 121. [CrossRef]

24. Nordstrom, P.A.; Wilson, L.L.; Kelsey, T.W.; Maretzki, A.N.; Pitts, C.W. The use of focus group interviews to evaluate agriculture educational materials for students, teachers, and consumers. J. Ext. 2000, 38, 5.

25. White, D.J.; Arnold, M.E.; Lesmeister, M. Using focus groups to evaluate youth development program direction. J. Ext. 2008, 46, 6.

26. Minitab 16 Statistical Software. [Computer Software]. Minitab, Inc.: State College, PA, USA, 2010; Available online: http//www.minitab.com (accessed on 20 May 2016). 
27. Schwebel, D.C.; Pickett, W. The role of child and adolescent development in the occurrence of agricultural injuries: An illustration using tractor-related injuries. J. Agromed. 2012, 17, 214-224. [CrossRef] [PubMed]

28. Myers, J.R.; Hendricks, K.J. Agricultural tractor overturn deaths: Assessment of trends and risk factors. Am. J. Ind. Med. 2010, 53, 662-672. [CrossRef] [PubMed]

29. United States Department of Labor. Child Labor Regulations, Orders and Statements of Interpretation. Child Labor Violations-Civil Money Penalties, 76 Fed. Reg. 54836 (to be codified at 29 C.F.R. pt. 570 \& 579); 2011. Available online: https://www.dol.gov/opa/media/press/whd/whd20111250.htm (accessed on 6 September 2011).

30. Jepsen, S.D. The U.S. Department of Labor's Tractor and Machinery Certification Program: Management Styles and Perceptions Held by Community Stakeholders and Instructors. J. Agric. Saf. Health 2012, 18, 217-232. [CrossRef] [PubMed]

31. The Safety in Agriculture for Youth 2015 Program Report. Available online: http:/ /www.eXtension.org/ agsafety (accessed on 1 October 2015).

32. The National Council for Agricultural Education's 2015 National AFNR Standards. Available online: https:/ / www.ffa.org/thecouncil/afnr (accessed on 4 May 2015).

(C) 2017 by the authors; licensee MDPI, Basel, Switzerland. This article is an open access article distributed under the terms and conditions of the Creative Commons Attribution (CC-BY) license (http://creativecommons.org/licenses/by/4.0/). 